on which type of bulb is used and the peculiarities of each enlarger. Using a No. 2 photoflood and a lens aperture of $\mathrm{f12}, \mathrm{I}$ find an average exposure to be in the region of ten seconds for an enlargement of 2 diameters. So far as possible ground glass plates in any position in the optical system of the enlarger should be dispensed with. They disperse the light and reduce the contrast.

Experiment has proved both Kodak and Ilford gaslight papers grade IV to be equally suitable. The Kodak paper, if anything, is a shade more contrasty. Glazing, if convenient, is well worth while. For development Kodak Special Developer D. 163 has given the best results, and if diluted 1 to 1 instead of 1 to 3 and used warm $\left(100^{\circ} \mathrm{F}\right.$. or $38^{\circ} \mathrm{C}$.) gives more contrast than many of the special contrast developers. The print " comes up "very quickly because of the temperature of the developer, but exposure can be regulated to give a two-minute development time. Fixing in double strength acid fixer clears the print still further due to the slight reducing effect of the hypo.

DeParTMENT OF GeOLOGY,

D. N. SAMPSON.

SHEFFIELD UNIVERSITY. 11 th October, 1949.

\title{
REFERENCES
}

Dollar, A. T. J. Nature, March, 1948, vol. 161, 358.

LeClercQ, S. Ann. Soc. géol. de Belgique, 1928, vol. 52.

WALTON, J, Nature, 1928, vol. 122, 571 .

\section{BOREHOLE SECTIONS AT ROSENEATH AND ROW}

SiR,-In his recent paper on "The Gareloch Re-Advance Moraine" (Geol. Mag., lxxxv, 239-244), Dr. J. G. C. Anderson has discussed the interesting section of raised beach and moraine deposits seen in the cliff along the north-western side of Row Point, and has remarked on the absence of any similar evidence with regard to the internal structure of Roseneath Point. Some war-time borings, which provided sections on both sides of the loch entrance to 60-70 feet deeper than the base of the Row Point exposures, may now be placed on record.

During the construction of a military port, the Consulting Engineers to the scheme maintained the possibility, despite geological arguments to the contrary, that the Row and Roseneath spits might be based, at no great depth, on a solid rock bar; in which case a considerable amount of blasting might be necessary to clear a channel adequate for vessels of 30 feet draught at all states of the tide. A detachment of 7 Boring Section, R.E., put down three holes, in July, 1941, to decide the matter. The holes were restricted to testing to a depth of 30 feet below low water mark, and all of them failed to reach solid rock within this limit.

The first hole was sited at high water mark on the outermost point of the Roseneath spit. After casing-off 8 feet of loose shingle the hole passed through 52 feet of thinly-bedded blue-grey clays and silts to its finishing depth of 60 feet. The second hole also was drilled from high water mark on the Roseneath spit, but to the south of the pier, and at about the same distance from it as No. 1 . The section proved was practically identical with that of No. 1 : shingle, 8 feet ; blue-grey clays and silts, 53 feet. The third hole was drilled from a barge, which was grounded after manoeuvring into position at high tide, about ten yards south-east of the navigation beacon at the outer end of the Row spit. The section in this hole was: shingle, 26 feet; soft blue-grey clays and silts 30 feet. 
A channel to 30 feet below Chart Datum over a width of 400 feet was dredged subsequently at Row Point without encountering any solid rock. A large portion of the 150,000 cubic yards removed was "ballast", and was used for filling-in behind the 150-ton floating crane berth at Faslane Bay.

\author{
35 BARKLEY ROAD, \\ PARKTOWN, \\ JOHANNESBURG. \\ 8th September, 1949.
}

\title{
T. O. MORRIS.
}

\section{REVIEWS}

landscape as Developed by the Processes of Normal Erosion. By C. A. Cotron. 2nd edition, pp. 507, with 375 figures. Whitcombe and Tombs, Ltd., Christchurch, New Zealand. 1948.

The first edition of this book was published by the Cambridge University Press in 1941. This second edition has been a good deal enlarged and in part rewritten. A good many photographs have also been added and the whole has been printed and produced in New Zealand. Meanwhile, Professor Cotton has written three other books : Geomorphology, an introduction to the study of land forms; Climatic Accidents in Landscape Making, about arid regions and glaciation; Volcanoes as Landscape Forms, a title which explains itself. The last two and the present book form a trilogy, which covers the whole subject of landscape making so far as now developed. The one section of the subject which has not yet been worked out in detail is landscape in wet tropical climates, except by Sapper, in German, and by the American geologists in Hawaii.

Naturally the examples are chosen and most of the photographs are taken from New Zealand, which affords very fine specimens of nearly all the types of scenery attributed to what is generally known as normal landscape making - that is the action of water and rivers. As a matter of fact this is not really more normal than anything else, such as glaciation, aridity, and volcanoes, but it is much commoner, although it should be remembered that it is estimated that about one-fifth of the whole land surface of the earth is arid, much of it absolute desert and therefore not much seen.

The work of W. M. Davis is very largely quoted, and a great number of his diagrams are reproduced, either directly or redrawn. Occasionally in these the perspective has not quite come off, especially in meanders, and in a few instances one wonders whether Davis really saw anything like that or whether he invented the whole thing. The general impression given by most of the photographs in this as well as the other books, is that the scenery of New Zealand is very exaggerated, and most remarkably varied.

While it is perhaps permissible to express a little scepticism as to some of the Davisian diagrams, Professor Cotton is to be heartily congratulated on the general success of the book, which is about the best non-American work on the subject. It is eminently readable, and is suited both to the general reader and to the specialist.

R. H. R.

The Geology of Water Supply. By Sir Cyril S. Fox. pp. $x$ and 209, with 49 figures and xxiii photographs. The Technical Press, Ltd., 1949. Price 25s.

Sir Cyril Fox has a life's experience of the practical application of geology to everyday problems. This book is written to give some of that experience to others but, as he says in the Foreword: "books ... cannot by mere reading, provide that information gained by actual experience." Throughout, the text points are illustrated from Sir Cyril's own experience or by quotations from that of others. Naturally, many of the examples are drawn from India. 